\title{
The Fuzzy Mathematical Evaluation of New Energy Power Generation Performance
}

\author{
Baoling Fang*
}

Weifang University of Science and Technology, Shandong, Shouguang, China

\begin{abstract}
With the rapid development of new energy industry, there are more and more evaluation researches about it. On the basis of consulting lots of reference, I determine the evaluation system of new energy power generation performance in this paper, and determine the weight of each evaluation index by employing hierarchical comparison method. Using fuzzy mathematical knowledge to establish the fuzzy comprehensive evaluation model of new energy power generation performance, it is divided into 5 levels. The first-level index judgment vector could be obtained by using expert judgment method to judge the second-level index. Grade judgment vector of new energy power generation performance could be obtained through first-level index weight vector. And the levels of new energy power generation performance could be determined based on the maximum principle.
\end{abstract}

Keywords: Evaluation, fuzzy comprehensiveness, new energy power generation, performance.

\section{INTRODUCTION}

Since reform and opening up, new energy industry develops rapidly in China. As the development of wind energy, solar energy, biomass power generation, nuclear energy and intelligent electric grid, new energy power is widely used. Government and civilian organizations have invested in new energy construction massively while new energy power ability is increased fleetly. On this background, there are more and more related researches on new energy power generation performance evaluation $[1,5]$.

\section{THE ESTABLISHMENT OF INDEX SYSTEM OF NEW ENERGY POWER GENERATION PERFOR- MANCE EVALUATION}

Based on the field work combined with lots of reference, 17 rating indexes from four aspects of new energy power generation performance evaluation could be determined in this paper [2]. The specific details see Table 1.

\section{BRIEF INTRODUCTION OF FUZZY MATHE- MATICS COMPREHENSIVE EVALUATION METHOD}

Fuzzy mathematics comprehensive evaluation method is one of the most common methods in fuzzy decision problem, which is also a comprehensive evaluation method to the things affected by multiple evaluation indexes based on fuzzy mathematics. The aim is to determine the factor sets and judgments sets of all evaluation indexes by using fuzzy mathematics knowledge system, and structure the grade evaluation matrix, fix the judgement grade, thereby get the overall evaluation [3].
1. Determine the evaluation factor set $P=\left\{p_{1}, p_{2}, \cdots, p_{n}\right\}$, there are $\mathrm{n}$ kinds of evaluation indexes;

2. Determine the grade evaluation set $V=\left\{v_{1}, v_{2}, \cdots, v_{m}\right\}$, and $\mathrm{m}$ is the judgement grade number.

3. Determine the fuzzy evaluation matrix $R=\left(r_{i j}\right)_{n \times m}$, the basic method can be divided into two steps:

(1) Make a grade judgement $f\left(p_{i}\right)(i=1,2, \cdots, n)$ to all index factors $\mathrm{P}$, you can get a fuzzy mapping $f$, from $\mathrm{P}$ to $\mathrm{V}$, namely

$f: P \rightarrow F(P), p_{i} \rightarrow f\left(p_{i}\right)=\left(r_{i 1}, r_{i 2}, \cdots, r_{i m}\right) \in F(V)$

(2) You can induce a fuzzy relation $R_{f} \in F(P \times V)$ from the fuzzy mapping $f$, namely

$R_{f}\left(p_{i}, v_{i}\right)=f\left(p_{i}\right)\left(v_{i}\right)=r_{i j}, i=1,2, \cdots, n ; j=1,2, \cdots, m$,

Thereby the fuzzy evaluation matrix $R=\left(r_{i j}\right)_{n \times m}$ could be determined (Table 2).

(3) The determination of each evaluation index weight

The geometric average method is used to calculate the weight vector of each evaluation index, the specific process is divided into three steps:

(i) Product each line elements in comparison matrix and get vector $\alpha$;

(ii) Square root vector $\alpha \mathrm{n}$ times, and vector $\beta$;

(iii) Carry out normalization processing to vector $\beta$, and get index weight vector $\gamma$.

(4) Consistency check 
Table 1. New energy power generation performance evaluation index system.

\begin{tabular}{|c|c|c|}
\hline & First-Level Index & Second-Level Index \\
\hline \multirow{4}{*}{ New energy power generation performance evaluation index system $P$} & Economic A & $\begin{array}{c}\text { Investment cost A1; } \\
\text { Operation and maintenance cost A 2; } \\
\text { Electricity cost A 3; } \\
\text { Fuel cost A 4; } \\
\text { Investment recovery period A } 5 ;\end{array}$ \\
\hline & Environment B & $\begin{array}{c}\mathrm{CO} 2 \text { emissions B1; } \\
\text { SO2 emissions B2; } \\
\text { Noise B3; }\end{array}$ \\
\hline & Society $\mathrm{C}$ & $\begin{array}{c}\text { Social acceptance C 1; } \\
\text { Land use C 2; } \\
\text { Social benefits C 3; } \\
\text { Providing employment C4 }\end{array}$ \\
\hline & Technology D & $\begin{array}{l}\text { Technical efficiency D1; } \\
\text { Initial energy ratio D2; } \\
\text { Security D3; } \\
\text { Maturity D4; } \\
\text { Reliability D5 }\end{array}$ \\
\hline
\end{tabular}

Table 2. 1-9 scale value.

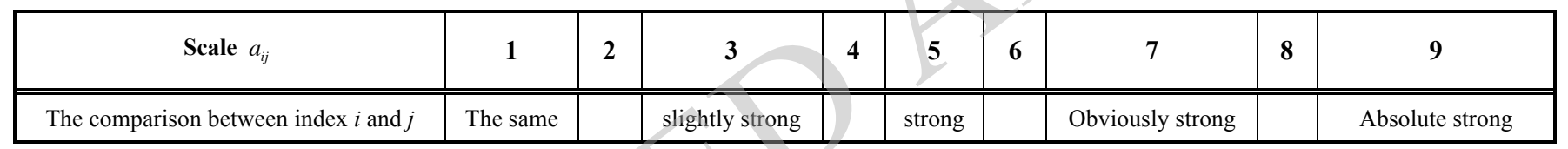

Consistency check process has three steps:

(i) Calculate consistency index:

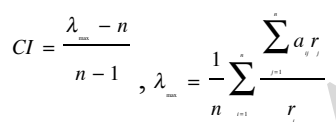

as the largest eigenvalue;

(ii) Determine random consistency index $R I$ according to evaluation index number $n$, the specific values are shown in Table 3.

(iii) Calculate the consistency ratio $C R=\frac{C I}{R I}$, when $C R<0.10$, pass the consistency check.

(5) Get the comprehensive evaluation vector $w=\gamma^{T} R$ by using multiply operation in matrix according to each evaluation index weight and evaluation matrix.

\section{THE FUZZY EVALUATION MODEL OF NEW ENERGY POWER GENERATION PERFORMANCE}

(1) Determine the evaluation index factor set of new energy power generation performance
$P=\left\{p_{1}, p_{2}, \cdots, p_{17}\right\}$, and draw the hierarchical structure diagram of evaluation index. The specific details are shown in Fig. (1).

Determine 17 second-level index grade evaluation set of new energy power generation performance $V=\left\{v_{1}, v_{2}, \cdots, v_{5}\right\}$, that is, according to certain classification principle, all second-level indexes are divided into 5 evaluation levels (Table 4). At the same time the evaluation results of new energy power generation performance are divided into 5 levels: good, better, general, poor, very poor $[4,6,7]$.

(3) Determine the fuzzy evaluation matrix $R=\left(r_{i j}\right)_{n \times m}$

The expert judgment method is used to carry out the second-level index grade judgement of new energy power generation [8], and the group includes 10 experts. Thus we could get the following in Fig. (1):

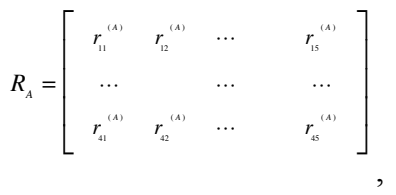

Table 3. Random consistency index.

\begin{tabular}{|c|c|c|c|c|c|c|c|c|c|c|c|c|c|}
\hline $\boldsymbol{n}$ & $\mathbf{1}$ & $\mathbf{2}$ & $\mathbf{3}$ & $\mathbf{4}$ & $\mathbf{5}$ & $\mathbf{6}$ & $\mathbf{7}$ & $\mathbf{8}$ & $\mathbf{9}$ & $\mathbf{1 0}$ & $\mathbf{1 1}$ & $\mathbf{1 2}$ & $\mathbf{1 1}$ \\
\hline \hline$R I$ & 0 & 0 & 0.58 & 0.90 & 1.12 & 1.24 & 1.32 & 1.41 & 1.45 & 1.49 & 1.51 & 1.54 \\
\hline
\end{tabular}




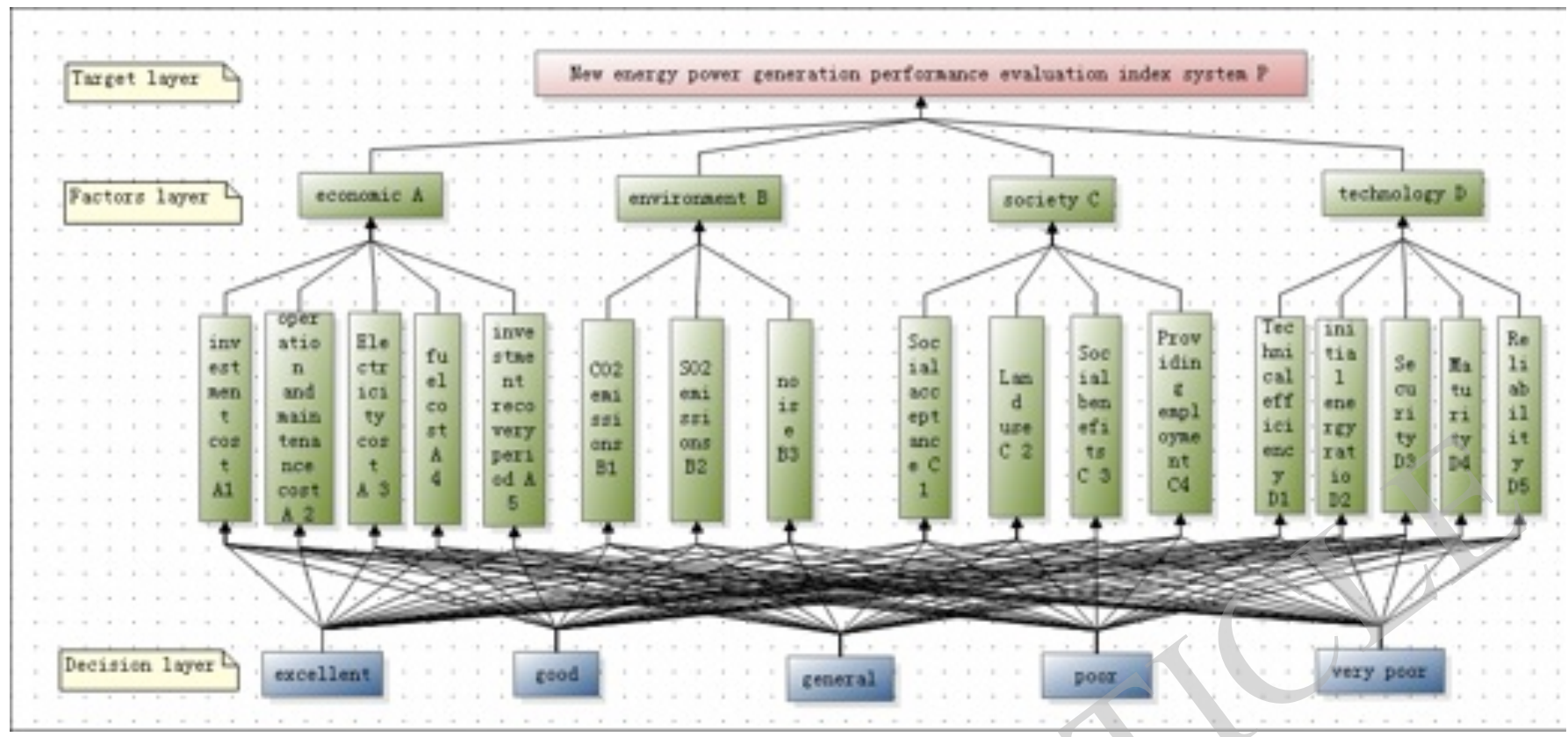

Fig. (1). The hierarchical structure diagram.

and $r_{i j}=$ the number of $\mathrm{j}$ level experts $/ 10$.

Similarly available: $R_{B}, R_{C}, R_{D}$.

(4) Determine the evaluation index weights of each level

(i) Select 10 expert to score and get the average value, confirm the influence between each index, thereby determine comparative matrix: A, B, C, D, P; (ii) Calculate the index weight vector of each level, and get five weight vector: $\gamma_{A}, \gamma_{B}, \gamma_{C}, \gamma_{D}, \gamma_{P}$.

(iii) Carry out consistency check.

(5) According to the corresponding second-level index weights, calculate and get five fuzzy evaluation matrix of first-level index:

Table 4. The second-level evaluation index levels of new energy power generation performance.

\begin{tabular}{|c|c|c|c|c|c|}
\hline The Second-Level Index & & & Level & & \\
\hline Investment cost $A 1$ & low & lower & general & higher & high \\
\hline Operation and maintenance cost A 2; & low & lower & general & higher & Very high \\
\hline Electricity $\operatorname{cost} A$ 3; & low & lower & general & higher & Very high \\
\hline Fuel cost A 4; & low & lower & general & higher & Very high \\
\hline Investment recovery period A 5; & short & shorter & general & longer & Very long \\
\hline CO2 emissions B1; & little & less & general & more & Very more \\
\hline SO2 emissions B2; & few & few & general & more & Very more \\
\hline Noise B3; & small & small & general & larger & Very larger \\
\hline Social acceptance C 1; & strong & stronger & general & poor & Very poor \\
\hline Land use C 2; & reasonable & More reasonable & general & poor & Very poor \\
\hline Social benefits C 3; & high & high & general & poor & Very poor \\
\hline Providing employment $\mathrm{C} 4$; & more & more & general & few & Very few \\
\hline Technical efficiency D1; & high & high & general & poor & Very poor \\
\hline Initial energy ratio D2; & high & high & general & poor & Very poor \\
\hline Security D3; & safe & safer & general & poor & Very poor \\
\hline Maturity D4; & mature & More mature & general & poor & Very poor \\
\hline Reliability D5; & reliable & More reliable & general & poor & Very poor \\
\hline
\end{tabular}


Table 5. The comparison matrix and the test results of first-level index aiming at target layer.

\begin{tabular}{|c|c|c|c|c|c|c|c|}
\hline \multirow{2}{*}{$\begin{array}{l}\text { The Target Layer } \\
\text { First-Level Index }\end{array}$} & \multicolumn{5}{|c|}{ New Energy Power Generation Performance Evaluation Index System P } & \multirow{2}{*}{ The Largest Eigenvalue } & \multirow{2}{*}{ The Consistency Ratio } \\
\hline & Economic A & Environment B & Society C & Technology D & Weight & & \\
\hline Economic A & 1 & $1 / 6$ & $1 / 2$ & 3 & 0.1161 & \multirow{4}{*}{4.0777} & \multirow{4}{*}{0.0291} \\
\hline Environment B & 6 & 1 & 4 & 9 & 0.6293 & & \\
\hline Society C & 2 & $1 / 4$ & 1 & 5 & 0.2064 & & \\
\hline Technology D & $1 / 3$ & $1 / 9$ & $1 / 5$ & 1 & 0.0482 & & \\
\hline
\end{tabular}

Table 6. The comparison matrix and the test results of second-level index aiming at first-level economic A.

\begin{tabular}{|c|c|c|c|c|c|c|c|c|}
\hline First-Level Index & \multicolumn{6}{|c|}{ Economic A } & \multirow[b]{2}{*}{$\begin{array}{c}\text { The } \\
\text { Largest } \\
\text { Eigenvalue }\end{array}$} & \multirow{2}{*}{$\begin{array}{l}\text { The } \\
\text { Consis- } \\
\text { tency } \\
\text { Ratio }\end{array}$} \\
\hline Second-Level Index & $\begin{array}{c}\text { Investment } \\
\text { Cost A1 }\end{array}$ & $\begin{array}{l}\text { Operation and } \\
\text { Maintenance } \\
\text { Cost A } 2\end{array}$ & $\begin{array}{c}\text { Electricity } \\
\text { Cost A } 3\end{array}$ & $\begin{array}{l}\text { Fuel } \\
\text { Cost } \\
\text { A } 4\end{array}$ & $\begin{array}{c}\text { Investment } \\
\text { Recovery } \\
\text { Period A } 5\end{array}$ & Weight & & \\
\hline Investment cost $\mathrm{A} 1$ & 1 & $1 / 2$ & $1 / 4$ & $1 / 5$ & $1 / 9$ & 0.0458 & \multirow{5}{*}{5.0237} & \multirow{5}{*}{0.0053} \\
\hline Operation and maintenance cost A 2 & 2 & 1 & $1 / 2$ & $1 / 3$ & $1 / 5$ & 0.0864 & & \\
\hline Electricity cost A 3 & 4 & 2 & 1 & $1 / 2$ & $1 / 3$ & 0.1573 & & \\
\hline Fuel cost A 4 & 5 & 3 & 2 & 12 & $1 / 2$ & 0.2553 & & \\
\hline Investment recovery period A 5 & 9 & 5 & 3 & 2 & 1 & 0.4551 & & \\
\hline
\end{tabular}

Table 7. The comparison matrix and the test results of second-level index aiming to first-level index environment $B$.

\begin{tabular}{|c|c|c|c|c|c|c|}
\hline First-Level Index & & Environmen & & & & \\
\hline Second-Level Index & $\mathrm{CO}_{2}$ Emissions B1 & $\mathrm{SO}_{2}$ Emissions B2 & The Noise B3 & The Weight & Tite Largest Ligentarue & Me Comsistency Răto \\
\hline CO2 emissions B1 & 1 & 1 & 8 & 0.4706 & \multirow{3}{*}{5.0237} & \multirow{3}{*}{0.0053} \\
\hline $\mathrm{SO} 2$ emissions $\mathrm{B} 2$ & 1 & 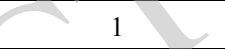 & 8 & 0.4706 & & \\
\hline Noise B3 & $1 / 8$ & $1 / 8$ & 1 & 0.0588 & & \\
\hline
\end{tabular}

Table 8. The comparison matrix and the test results of second-level index aiming at first-level index society $C$.

\begin{tabular}{|c|c|c|c|c|c|c|}
\hline First-Level Index & \multicolumn{5}{|c|}{ Society C } & \multirow{2}{*}{ The Largest } \\
Second-Level Index & $\begin{array}{c}\text { Social Acceptance } \\
\text { C 1 }\end{array}$ & $\begin{array}{c}\text { Land Use } \\
\text { C 2 }\end{array}$ & $\begin{array}{c}\text { Social Benefits } \\
\text { C 3 }\end{array}$ & $\begin{array}{c}\text { Providing Employment } \\
\text { C4 }\end{array}$ & Weight & $\begin{array}{c}\text { Eigenvalue } \\
\text { Ratio }\end{array}$ \\
\hline \hline Social acceptance C1 & 1 & 5 & 3 & 2 & 0.4878 & \\
\hline Land use C2 & $1 / 5$ & 1 & $1 / 3$ & $1 / 2$ & 0.0891 & 4.1065 \\
Social benefits C3 & $1 / 3$ & 3 & 1 & $1 / 2$ & 0.1753 & 0.0399 \\
\hline Providing employment C4 & $1 / 2$ & 2 & 3 & 1 & 0.2479 & \\
\hline
\end{tabular}

$R_{P}=\left(\begin{array}{llll}\gamma_{A}^{T} R_{A} & \gamma_{B}^{T} R_{B} & \gamma_{C}^{T} R_{C} & \gamma_{D}^{T} R_{D}\end{array}\right)^{T}$

According to the first-level index weight, get grade evaluation vector of new energy power generation performance:

$w=\gamma_{P}^{T} R_{P}$,

Based on the maximum principle, the biggest component of $w$ is the grade of new energy power generation performance.

\section{MODEL SOLVING AND ITS APPLICATION}

\subsection{Model Solving}

By visiting the experts, determine the corresponding comparison matrix, the specific results are shown in Tables 5-9.

\subsection{Model Application - The Evaluation of a Solar Power Generation Equipment}

(i) Ten experts give the grade evaluation of the secondlevel evaluation index of a solar power generation equipment [10-13]. The results are shown in Table $\mathbf{1 0 .}$ 
Table 9. The comparison matrix and the test results of second-level index aiming at first-level index technology $D$.

\begin{tabular}{|c|c|c|c|c|c|c|c|c|}
\hline \multirow{2}{*}{$\begin{array}{c}\text { First-Level Index } \\
\text { Second-Level Index }\end{array}$} & \multicolumn{6}{|c|}{ Technology D } & \multirow{2}{*}{$\begin{array}{c}\text { The } \\
\text { Largest } \\
\text { Eigenvalue }\end{array}$} & \multirow{2}{*}{$\begin{array}{c}\text { The } \\
\text { Consistency } \\
\text { Ratio }\end{array}$} \\
\hline & $\begin{array}{c}\text { Technical } \\
\text { Efficiency D1 }\end{array}$ & $\begin{array}{c}\text { Initial Energy } \\
\text { Ratio D2 }\end{array}$ & $\begin{array}{c}\text { Security } \\
\text { D3 }\end{array}$ & $\begin{array}{c}\text { Maturity } \\
\text { D4 }\end{array}$ & $\begin{array}{c}\text { Reliability } \\
\text { D5 }\end{array}$ & $\begin{array}{c}\text { The } \\
\text { Weight }\end{array}$ & & \\
\hline Technical efficiency D1 & 1 & 3 & $1 / 3$ & $1 / 6$ & $1 / 6$ & 0.0701 & \multirow{5}{*}{5.0846} & \multirow{5}{*}{0.0189} \\
\hline Initial energy ratio D2 & $1 / 3$ & 1 & $1 / 5$ & $1 / 7$ & $1 / 8$ & 0.0373 & & \\
\hline Security D3 & 3 & 5 & 1 & $1 / 2$ & $1 / 2$ & 0.1869 & & \\
\hline Maturity D4 & 6 & 7 & 2 & 1 & 1 & 0.3481 & & \\
\hline Reliability D5 & 6 & 8 & 2 & 1 & 1 & 0.3575 & & \\
\hline
\end{tabular}

Table 10. The second-level evaluation index grade judgement results of a solar power generation equipment performance.

\begin{tabular}{|c|c|c|c|c|c|}
\hline Second-Level Index & \multicolumn{5}{|c|}{ Level } \\
\hline \hline Investment cost A1; & 3 & 5 & 1 & 1 & 0 \\
\hline Operation and maintenance cost A 2; & 1 & 3 & 5 & 1 & 0 \\
\hline Electricity cost A 3; & 2 & 4 & 4 & 0 & 0 \\
\hline Fuel cost A 4; & 5 & 3 & 2 & 0 & 0 \\
\hline Investment recovery period A 5; & 0 & 2 & 5 & 2 & 1 \\
\hline CO2 emissions B1; & 0 & 1 & 7 & 1 & 1 \\
\hline SO2 emissions B2; & 0 & 2 & 6 & 2 & 0 \\
\hline Noise B3; & 1 & 2 & 4 & 2 & 1 \\
\hline Social acceptance C 1; & 4 & 5 & 1 & 0 & 0 \\
\hline Land use C 2; & 2 & 4 & 3 & 1 & 0 \\
\hline Social benefits C 3; & 4 & 3 & 3 & 0 & 0 \\
\hline Providing employment C4; & 1 & 2 & 4 & 3 & 0 \\
\hline Technical efficiency D1; & 0 & 2 & 6 & 1 & 1 \\
\hline Initial energy ratio D2; & 1 & 3 & 5 & 1 & 0 \\
\hline Security D3; & 2 & 3 & 4 & 1 & 0 \\
\hline Maturity D4; & 1 & 3 & 6 & 0 & 0 \\
\hline Reliability D5; & 3 & 2 & 4 & 1 & 0 \\
\hline
\end{tabular}

(ii) Based on data reduction, using the matrix multiplication calculation, we can get the evaluation vector of this solar power generation equipment performance, that is,

$w=\left(\begin{array}{lllll}0.0971 & 0.2199 & 0.5154 & 0.1287 & 0.0389\end{array}\right)$

According to the maximum principle, we can get the conclusion that the evaluation level of the solar power generation equipment performance is general.

\section{CONCLUSION}

New energy is very important to a country, and its power performance evaluation is particularly significant.
Introducing the fuzzy mathematical evaluation model, considering the four factors including technology, economy, environment and the society, new energy power generation performance is evaluated by this model. It is simple, fair and fast to carry out an evaluation, which also provide theoretical basis for the sustainable development of new energy.

Due to the limited space and limited reading, it may have some defects in establishing the evaluation index system of new energy power generation performance. I hope this paper could inspire readers and promote the development of new energy power generation enterprise.

\section{CONFLICT OF INTEREST}

The author confirms that this article content has no conflict of interest.

\section{ACKNOWLEDGEMENTS}

Declared none.

\section{REFERENCES}

[1] Tao, L. The environment impact evaluation based on urban land planning project. Int. J. Earth Sci. Engin., 2015, 8(2), 196-204.

[2] Araki, I.; Tatsunokuchi, M.; Nakahara H.; Tomita, T. Bifacial PV system in aichi airport-site demonstrative research plant for new energy power generation. Sol. Energy Mater. Solar Cel., 2009, 93(6), 911-916.

[3] Lund, P.D. Fast market penetration of energy technologies in retrospect with application to clean energy futures. Appl. Energy, 2010, 87(11), 3575-3583.

[4] Dhakar, L.; Liu, H., Tay, F.E.H.; Lee, C. A new energy harvester design for high power output at low frequencies. Sensors Actuat. APhys., 2013, 199, 344-352.

[5] Ming, Z.; Song, X.; Mingjuan, M.; Xiaoli, Z. New energy bases and sustainable development in China: a review. Renew. Sustain. Energy Rev, 2013, 20, 169-185.

[6] Chiuta, S.; Everson, R.C.; Neomagus, H.W.J.P.; Dmitri, G.B. Experimental performance evaluation of an ammonia-fuelled microchannel reformer for hydrogen generation. Int. J. Hydrogen Eneroy, 2014, 39(13), 7225-7235.

[7] Petkov, V.M.; Zimparov, V.D.; Bergles, A.E. Performance evaluation of ducts with non-circular shapes: laminar fully developed flow and constant wall temperature. Int. J. Thermal. Sci., 2014, 79, 220-228

[8] Zhang, D.; Qin, J.; Feng, Y.; Ren, F.; Bao, W. Performance evaluation of power generation system with fuel vapor turbine onboard hydrocarbon fueled scramjets. Energy, 2014, 77, 732-741.

[9] W. Bochun. The new energy system social evaluation model method research. New Energy Resour New Mat., 2004, 20-24. 
[10] Ling, Z.; Jianxin, F.; Peng, Z. New eergy power generation performance evaluation research were reviewed. Technoecon. Manage. Res., 2014, 1, 3-8.

[11] Zhonggeng, H. Methods and applications of mathematical modeling. Beijing: Higher Education Press, 2005.
[12] Jingwei, S.; Xinyi, W. Application of comprehensive evaluation for the quality of the physical and chemical laboratory by fuzzy mathematics. Shanghai J. Prev. Med., 2002, 14, 265-266.

[13] Yuehua, W. Study on the effective assessment of university internal control based on the fuzzy comprehensive assessment. Chongqing Higher Educ. Res., 2013, 3, 27-32.

Received: January 6, 2015

Revised: May 20, 2015

Accepted: June 19, 2015

(C) Baoling Fang; Licensee Bentham Open.

This is an open access article licensed under the terms of the Creative Commons Attribution Non-Commercial License (http://creativecommons.org/licenses/ by-nc/3.0/) which permits unrestricted, non-commercial use, distribution and reproduction in any medium, provided the work is properly cited. 